\title{
7. «Så lite sårbar som mulig, for å kunne fremme ubestridelige krav»
}

\section{Helsesårbarhet, menneskerettigheter og skam i Jan Grues Jeg lever et liv som ligner deres. En levnetsbeskrivelse}

\section{Tonje Vold}

Sammendrag Kapittelet presenterer en lesning av Jan Grues bok Jeg lever et liv som ligner deres. En levnetsbeskrivelse (2018), som legger vekt på helsesårbarhet og belyser verkets avanserte diskusjoner av sammenhengene mellom sårbarhet, skam og menneskerettigheter. Teoretisk bygger lesningen på innsikter fra litteratur og menneskerettighetsfeltet og tverrfaglig funksjonshemmingsforskning, som begge retter et kritisk blikk mot litteratur- og kulturhistoriens representasjon av sårbare grupper og individer.

Nøkkelord Jan Grue | funksjonshemming | menneskerettigheter | skam | selvbiografi

Abstract This chapter adresses Jan Grues memoir Jeg lever et liv som ligner deres. En levnetsbeskrivelse, 2018 (I Live a Life Like Yours. A Memoir, 2021) from a perspective of human health vulnerability. The reading shows the advanced debates Grue's book allows for concerning how vulnerability, shame and human rights are connected. Theoretically, my reading builds on insights from literature and human rights and disability studies, and critique of the representations of vulnerable groups and individuals in literature and culture.

Keywords Jan Grue I disability | human rights I shame I memoir 
Jan Grues forfatterskap rommer fagbøker i retorikk og tverrfaglige funksjonshemmingsstudier, samt skjønnlitterær prosa, noveller og en roman. Utgivelsen Jeg lever et liv som ligner deres: En levnetsbeskrivelse (2018) skiller seg ut i denne sammenhengen ved et selvbiografisk tema og en essayistisk stil. Sentralt står Grues helse, muskelsykdom og funksjonshemmingene som er konsekvensen av denne. Gjennom en patografisk fortelling som understreker situasjonell sårbarhet knyttet til redusert helse, bidrar Jeglever et liv som ligner deres til en utvidet forståelse av hvordan sårbarhet og menneskeverd forstås i velferdsstaten.

Det er alltid en fare for at «sårbarhet», når denne forstås som en universell eller eksistensiell kvalitet, noe som deles av alle mennesker, samtidig forsvinner som presist begrep (Butler, 2016; Ganteau, 2015; Dancus, Hyvönen \& Karlsson, 2020). Dancus, Hyvönen og Karlsson argumenterer derfor for at sårbarhetsbegrepet må forstås opp mot en sårbarhetspolitikk (2020, s. 3), som i skandinavisk sammenheng involverer velferdsstaten som en viktig kontekst. Sårbarhetsforskere som fokuserer på funksjonshemming, har forsøkt å gjøre opp for tidligere funksjonshemmingsaktivisters overdrevne understreking av autonomi og uavhengighet ved å tematisere en «unequal distribution of vulnerability» (Bergenmar, 2020, s. 152). Analysen min av Grues levnetsskildring kan leses i forlengelsen av disse perspektivene, men som det vil bli klart i løpet av kapittelet, mener jeg det er hensiktsmessig å kople litterære tematiseringer av sårbarhet i velferdsstaten til innsikter utviklet innenfor teorifeltet litteratur og menneskerettigheter.

Dette teorifeltet, litteratur og menneskerettigheter, har særlig to mål: å lese ut fortellinger om menneskerettigheter i litteraturen, og å se hvordan vitnemål, fortellinger og litteraturteori bidrar til å utvikle filosofi, lover og praksis. I sammenheng med utviklingen av en lesning om sårbarhet i Grues verk kan teoriene bidra på to måter.

For det første belyser teoriene tematikken i Grues verk med betydning for forståelsen av helsesårbarhet i velferdsstaten. Slik jeg ser det, vil lesninger som beror på litteratur og menneskerettigheter, både kunne vise fram hvordan det foregår ulik distribusjon av menneskeverd, noe som blant annet kan innebære en svekkelse av retten til å være sårbar, og ulik distribusjon av basale rettigheter, noe som blant annet kan innebære en svekkelse av retten til å være autonom. Begge deler bidrar til livsbetingelsene i den moderne velferdsstaten, der helse defineres på økonomiske premisser. For det andre har teoriene analysert littercer form på måter som kaster lys over Grues verk. Historiker Lynn Hunt har særlig analysert romanen som en form som oppstod sammen med menneskerettighetsideene, og som en viktig teknologi for å utvikle disse ideene, særlig en empati med den andre, som skaper evnen til å anerkjenne den andres grunnleggende rettigheter (Hunt, 2007). 
Andre har snarere påpekt sammenhengen mellom vitnesbyrd, førstepersonsframstilling og rettighetskamp (Xiang, 2019; Schaffer \& Smith, 2004). Vitnesbyrdet er enkeltpersonens mulighet til å fremme krav på egne og andres vegne. Å utgi sin livshistorie er å løfte det private inn i offentligheten og sette søkelys på egne livsbetingelser, og kreve å bli lest og tatt på alvor. Grues verk kan ses i sammenheng med det Kay Schaffer og Sidonie Smith kaller en internasjonal «memoir boom», som har ført til økt oppmerksomhet om menneskerettigheter verden over: «Numerous life narratives attest to the resistance and resilience of individuals and groups as they struggle for freedom, justice and dignity», skriver de (2004, s. 3).

Ved å knytte an til innsikter fra litteratur og menneskerettighetsfeltet i lesningen av Jeg lever et liv som ligner deres framstår Grues utforsking av sårbarheten som et hovedtema i verket. Grues skildring av livet med og som en uvanlig kropp kan i denne lesningen bidra til et klarere begrep om hvordan helsesårbarhet, rettigheter og skam henger sammen i den norske velferdsstaten, og hva vitnesbyrdet bidrar med som sjanger. En slik utforsking kan være nyttig i ulike undervisningssammenhenger både i norsk og samfunnsfag. I tillegg utvikles de litterære funksjonshemmingsstudiene ved å inkludere sakprosa. Der litteraturvitere utforsker funksjonshemmingsperspektiver i skandinavisk litteratur, er det særlig fiksjonsfortellinger som analyseres (Simonhjell, 2010; Vold, 2014), det gjelder også når det er sårbarhetens politikk som er utgangspunktet (Bergenmar, 2020). Som sakprosa, memoarbok og et essayistisk verk er Grues bok derfor velegnet både om man vil utforske selvbiografiske fortellingers potensial for protest og sårbarhetens kontekstualitet (Koivunen, Kyrölä \& Ryberg, 2018, s. 12) i sakprosa og politikk.

Bruken av begrepet «helsesårbarhet» mener jeg er hensiktsmessig fordi det tydeliggjør hvilken form for sårbarhet det er snakk om, slik at en universell idé om sårbarhet unngås, og ikke alle sider ved et subjekt er like sårbare. I Jan Grues selvframstilling er det et poeng at han på andre måter er mer privilegert enn mange andre, også i Norge: med en «frihet ikke alle har. Til å være sanndrømt om fremtiden» (2018, s. 77), samtidig som kropp, sykdom og hjelpeapparat setter grenser for livet som leves. Begrepet helsesårbarhet skaper videre en motvekt til det tabloide «helseskam», som er i ferd med å feste seg i mediene. Å skape seg «et rom i verden» med boka er å skrive seg ut av skammen. "Det er denne skammen jeg vil skrive ut av meg nå, det er den jeg vil betrakte og legge fra meg» (Grue, 2018, s. 137). En vei ut av skammen er nettopp å akseptere denne formen for helsemessig sårbarhet. Boka kan fra dette perspektivet leses som et forsøk på å flytte diskusjonen om rettighetsgrunnlag og legitimere helsesårbarhet som et grunnlag for å stille krav. 


\section{LIVSFORTELLING SOM SÅRBAR: JEG, HAN, HUN OG DERE}

Med det som må være blant verdenslitteraturens ypperste beskrivelser av sykdom som sanselig erfaring, åpner Virginia Woolfs essay «On Being Ill» fra 1926 på en måte som kaster lys over flere av de overordnete temaene i dette kapittelet:

Considering how common illness is, how tremendous the spiritual change that it begins, how astonishing, when the lights of health go down, the undiscovered countries that are disclosed, what wastes and deserts of the soul a slight attack of influenza brings to light, what precipices and lawns sprinkled with bright flowers a little rise of temperature reveals, what ancient and obdurate oaks are uprooted in us in the act of sickness, how we go down into the pit of death and feel the waters of annihilation close above our heads and wake thinking to find ourselves in the presence of the angels and harpers when we have a tooth out and come to surface in the dentist's arm chair and confuse his 'Rinse the mouth - rinse the mouth' with the greeting of the Deity stooping from the floor of Heaven to welcome us - when we think of this and infinitely more, as we are so frequently forced to think of it, it becomes strange indeed that illness has not taken its place with love and battle and jealousy among the prime themes of literature» (Woolf, 1926, s. 32).

Forfattere skriver som om kroppen er en klar glassvegg sjelen ser gjennom, skriver Woolf i essayet. Men snarere er det tvert imot: Kroppen blander seg inn i alt mennesket opplever, tenker og sanser. «But of all this daily drama of the body there is no record», sier hun (Woolf, 1926, s. 33). Det er stor diskrepans mellom kroppen og helsesårbarheten som drama og den kulturelle representasjonen av fenomenene. Woolf viser videre sykdomssvekkelse som en estetisk styrke, noe som gir helt egne perspektiver, og som åpner opp for å se flere dimensjoner ved tilværelsen.

Slik jeg leser Jeg lever et liv som ligner deres, avdekker Grue flere slike ukjente landskap Woolf beskriver her, gjennom å plassere egen sykdom og funksjonsnedsettelser sentralt i skildringen. Nesten hundre år etter Woolf skriver han at vi lever $\mathrm{i}$ «en kultur der kroppene snarere er en rekvisitt, en kilde til skam eller stolthet, enn et åsted og rammene for et liv» (Grue, 2018, s. 83). I hans bok trer ikke kroppen fram som en glassklar flate, snarere framstår kroppen som et prisme, noe som står i forgrunnen og setter preg. Det kroppslige drama er både veldokumentert og skaper spenning.

Forfatteren framhever at det tok ham ti år å skrive boka. «Jeg tror jeg vet hvorfor det tok så lang tid», skriver Grue i et avsnitt der han beveger seg fra å beskrive funksjonshemmetes rettighetskamp til sin egen skriving, «jeg tror jeg gjenkjenner 
et behov for å kjempe på fast grunn, for å ikke gjøre seg mer sårbar enn man må» (Grue, 2018, s. 41). Han fortsetter:

Jeg tror jeg skriver om meg selv for å forstå verden, og at jeg i mange år ville være så lite sårbar som mulig, for å kunne fremme ubestridelige krav.

Det er en impuls jeg fremdeles kjenner, jeg vil ha orden i sysakene, jeg vil kjenne rettighetene mine. Samtidig er jeg stadig mer interessert i områdene der rettigheter er feil ord, der rasjonaliteten gir opp (Grue, 2018, s. 41).

Til hinder både for de litterære beskrivelsene Woolf ønsket seg, anerkjennelsen av sykdom som vesentlig erfaring og for rettighetskampen ligger en grunnleggende frykt for å eksponere seg selv som sårbar, og dermed avvises som rettighetshaver, en som ikke får komme til orde eller stille krav. Videre poengterer forfatteren interessen for det som ikke bare kan beskrives rasjonelt, noe som kanskje kan knyttes til det følelsesmessige, etiske og estetiske domenet.

Både å skrive patografiske memoarer og å fremme krav forutsetter en stemme. Tittelen Jeg lever et liv som ligner deres er en ytring som plasserer «jeg»-et som tekstens forutsetning. Ytringen framstår også som del av en dialog. Et «jeg» henvender seg enten til eller om noen, et «dere». Flertallsformen her gjør det imidlertid mer uklart hvem «deres» liv refererer til, enn dersom eiendomspronomenet var «ditt», siden «deres» impliserer en gruppe, som tilhøreren kan være, men ikke nødvendigvis er, del av. Tittelen fungerer dermed nettopp som en igangsetter for spørsmål om identitet og gruppetilhørighet. Hvem sine liv er det Grues liv ligner? I fortellingen som følger, knyttes det spesifikke utsagnet til foreldrenes liv: et privilegert akademisk osloliv (Grue, 2018, s. 9) Men som boktittel kan livene også implisere «funksjonsfriskes» liv, «funksjonshemmetes» liv og lesernes liv; som en bok som fremmer et vitnesbyrd om menneskeverd og rettferdighet, impliserer den offentligheten.

Jeg-et «lever», og i tittelens sentrum står «liv»: livet som leves, å «få seg et liv», og på hvilke vilkår Grue lever sitt, er hovedtemaet. Det er «jeg», som er tittelens første ledd, og forfatter og forteller Jan Grue som er den viktigste i fortellingen. I tillegg til et «jeg» og et «deres» konstrueres bokas sakprosafortelling i tillegg omkring en «han», en som ikke kan komme til orde selv. Grues sakprosafortelling etableres nemlig fra start omkring en arbeidstittel han ikke bruker: om å bli et menneske (2018, s. 15). En slik tittel ville bli misvisende siden det heller ville være veien til å forstå seg selv som det hele mennesket han alt er, han beskriver. Dessuten er tittelen How I Became a Human alt i bruk av Mark O'Brien (2012), en svært alvorlig funksjonshemmet poet som døde ung. O’Brien tar form av en dobbeltgjenger i boka, den Grue kunne vært: sykere, svakere, død - og den enda mer kon- 
troversielle, modige, utleverende og utsatte. En annen viktig tredjeperson er en «hun», Ida, ektefellen som sørger for at Grue ikke lider O’Briens skjebne som ensom. Dynamikken mellom jeg (Jan Grue), ham (Mark O’Brien), henne (Ida) og de ulike variantene av dere former Grues levnetsskildring, som dermed fra starten av postulerer liv som relasjonelle. Åpningen skaper et rom for fortellingen som skal utspille seg, det er en bok om å bli et helt menneske, der identiteten skapes i et sosialt rom, og et selvbiografisk vitnesbyrd henvendt til offentligheten.

For enhver innebærer oppveksten visse mer eller mindre vellykkete forsøk på å kople utenfrablikk til selvforståelsen, og å bearbeide, integrere eller avvise disse blikkene. Jan Grues liv utvikler seg med en tiltakende bevissthet om at sårbarheten er ulikt distribuert, og hans liv anses som spesielt skjørt. Fra bokas første setning og de første avsnittene er det klart at barnet Jan ikke visste hvordan andre så ham, nemlig som et sykt barn med kort levetid:

Fra tid til annen treffer jeg mennesker som kjente meg som barn, men som ikke ventet å møte meg som voksen. ... Av livssynslæreren min lærte jeg ordet liminalfase. Det beskrev den mest sårbare delen av et overgangsritual, der man befinner seg mellom to verdener. ... Det er i disse fasene det virkelig kan gå galt, men det er også i disse fasene transformasjonen skjer. Det er i disse fasene vi blir til. Uten dem går ikke verden videre (2018, s. 7).

Passasjen viser til mulighetene sårbarhet gir (som i Woolfs mer begrensete eksempel med det sansemessige potensialet i influensa og feber), men helsesårbarhetens liminale fases transformasjonspotensial kan i Grues verk ellers likevel ikke enkelt tas til inntekt for verdier som personlig vekst eller selvrealisering. Selv om antakelsen om levetid viser seg å bero på feildiagnostikk, ligger døden som et bakteppe for livsfortellingen, og som en påminnelse om risikoen ved å leve helsemessig sårbare liv.

\section{MENNESKERETTIGHETER, MENNESKEVERD OG SÅRBARHET I VELFERDSSTATEN}

Grues helsesårbarhet er knyttet både til fysisk svekkelse, til samfunnets forestillinger om sykdom og til implikasjonene begge deler har for livserfaringer, selvfølelse, forventninger til framtiden med mer. Ett av bokas hovedanliggender er å vise hvordan andres forestillinger om en former et menneske - enten de formidles tydelig eller ikke, ansikt-til-ansikt eller i samtidskulturen, og uansett om de preger en ubevisst, eller inngår i en ekstremt reflektert og selvbevisst dialog - og hvilke 
forestillinger som dominerer her og nå. Artikulasjonen av det å bli et menneske innebærer kartleggingen av andres forventning, og forstå og leve med et gitt utenfra-blikk, som skapes av medisinen og institusjonene: velferdsstatens blikk - eller diskurs. Det er lett å lese Grue gjennom hans foretrukne teoretiske perspektiv, diskursanalysen. ${ }^{1}$ Et alternativt perspektiv angir feltet litteratur og menneskerettigheter. For hvordan er sårbarhet og stigmatisering blitt til hinder for at noen kan gjøre sine krav gjeldende når det iboende menneskeverdet er grunnleggende?

Den enkleste definisjonen av sårbarhet i Grues bok er at «Sårbarhet er vissheten om hvor enkelt det kan gå galt» (2018, s. 125). At det ikke går galt, avhenger både av private og offentlige forpliktelser og ressurser. Den helsemessige sårbarheten Grue lever med, innebærer redsel for at systemet skal slutte å virke, noe som gjør rettighetene desto mer akutte å ivareta, det blir livsavgjørende at status anerkjennes. Rettigheter er dermed en annen siden av sårbarhet.. Flere forskere innenfor litteratur og menneskerettigheter har karakterisert menneskerettighetspraksiser som paradoksale (Anker, 2012; Cheah, 2006; Goldberg \& Moore, 2012). Menneskerettighetspraksis og -diskurser virker normativt, de bestemmer hvordan vi forstår hva et menneske er. Men menneskerettighetene er avhengig av noens anerkjennelse for å virke beskyttende. Både må rettighetene anerkjennes f.eks. av en stat, og den som gjør krav på å få rettighetene hørt, må anerkjennes som subjekt. Et eventuelt brudd på dem må også kvalifisere til anerkjennelse. Rettighetene er på langt nær sikre, men noe som innvilges av noen til noen (myndigheter, internasjonal lov). Slik skapes et rom for fortolkning og gradering av både subjekters og overgreps status. I denne sammenheng er det relevant at ikke alle kropper oppfattes som beskyttelsen verdig: Stigmatiserte grupper har historisk og i dag vanskelig for å gjøre sine krav om beskyttelse av menneskerettigheter gjeldende.

Arbeidet Grue og de ressurssterke foreldrene må gjøre for å få gjennomslag for krav, tyder på at ikke alle gruppers rettigheter anerkjennes i like stor grad, og at Grues redsel er helt reell. De formulerer klager, ombygger hus, krever og kjenner sine rettigheter: «jeg vil ha orden i sysakene, jeg vil kjenne rettighetene mine» (2018. 41). Velferdsstaten har på sin side dokumentert store deler av Grues liv gjennom ulike saksbehandlingsdokumenter. Papirarbeidet fra begge sider fyller permer som rituelt flyttes fra foreldrene til ham når han flytter hjemmefra. I en del av materialet er alle journalene medisinske rapporter som $i$ «depresjonens språk» (Grue, 2018, s. 51) beskriver en guttekropp del for del, eller hjelpere som får Grue til å føle seg som en ting, som «fraktgods, et logistisk problem» (Grue, 2018, s. 27).

1 Institusjoner stirrer på enkeltmennesker, underlegger dem sin kontroll, sier Grue, i forlengelse av Michel Foucault: «Det medisinske blikket, det genetiske blikket, det kliniske blikket, ser tydelig forskjell på [diagnoser]» (s. 37). 
I en annen del av materialet ser man en rettighetskamp utspille seg, avisutklipp om helsesårbarhet som ikke anerkjennes, «rettigheter som ikke innfris» (2018, s. 21). Det er mønstre i dette, familien krever ansvarstagen fra ulike aktører som ikke forholder seg til regler:

På tvers av sjangrene har disse papirene det til felles at de forsøker å stille noen til ansvar, noen som nekter. Reisebyrået som lovet å transportere en rullestol, og så glemte eller brøt løftene sine. Sykehuset som ikke fulgte opp, de statlige instansene som ikke fulgte sine egne regler. Institusjoner og organisasjoner har lang hukommelse, men bare når det passer dem. Ellers lever de, og begrunner sine avslag, i nuet (Grue, 2018, s. 25).

For å få innfridd krav må man anerkjennes som sårbar og hjelpetrengende, men for å orke det må man framstå sterk. De virkelig sårbare er de som ikke har noen til å hjelpe, som ikke har «en familie som mestret hjelpeapparatet» (Grue, 2018, s. 78).

FN-konvensjonen om funksjonshemming skal sikre «the full and equal enjoyment of all human rights and fundamental freedoms by all persons with disabilities and to promote respect for their inherent dignity» (UN, 2006). Grues bok viser imidlertid at den lange lista med basale rettigheter - «respect for home and the family, education, employment, health, participation in political and public life, participation in cultural life, recreation, leisure and sport, the right to life» (UN, 2006) - som konvensjonen lister opp, ikke kan tas for gitt innenfor velferdsstaten. Arbeider man hardt for å få det man har krav på, «blir man et krevende menneske: Ved å be om mer enn det som man blir tilbudt. Slik blir man et problem, ved å påpeke et problem», skriver Grue (2018, s. 105). Å bli «et problem» er noe man kan tåle, men det er neppe en identitet noen ønsker seg.

Enkelte menneskerettighetsforskere påpeker at det er de mest oppsiktsvekkende overgrep som framstår tydeligst. Funksjonshemming og sykdom er i seg selv noe ordinært og slik sett det motsatte av oppsiktsvekkende. Kronisk sykdom og ulike funksjonsnedsettelser er dessuten gjerne permanente og uten særlig mulighet for spektakulær utvikling. "Disability is part of the human condition», fastslår Verdens helseorganisasjons World Report on Disabilities (WHO, 2011): «Almost everyone will be temporarily or permanently impaired at some point in life, and those who survive to old age will experience increasing difficulties in functioning» (WHO, 2011, s. 1-3). Selv om dette normaliserer funksjonsnedsettelser, bidrar det også paradoksalt nok til at funksjonshemmede blir marginalisert som minoritet, og at helsesårbarhet overses. I tillegg kan funksjonshemmete overses eller miste status som sårbar gruppe fordi menneskerettighetstankegangen gjerne opererer 
med et abstrakt og allment, og dermed verken kjønnet, sykt eller rasialisert, subjekt. Elizabeth Anker påpeker at det nettopp er funksjonshemmingsforskere og -aktivister som har fremmet den beskeste kritikken mot en slik subjektsforståelse (Anker, 2012). Gjennom denne måten å forstå rettigheter på forsvinner kroppen til tross for at det i enkelte tilfeller nettopp er synlige eller forestilte aspekter ved den (kjønn, hudfarge, helsetilstand) som foranlediger krenkelser av menneskeverdet. Krav om like rettigheter fremmes videre på forskjellige prinsipper. Rettighetskampen for kvinner eller ikke-hvite subjekter handler om å oppnå anerkjennelse på like premisser som menn eller hvite subjekter. Kroppslig forskjell vil i de aller fleste tilfeller ses på som uvedkommende og som lite relevant. Utgangspunktet for rettighetskamp for folk med sykdom eller funksjonsnedsettelse stiller seg annerledes. Her må grunnleggende kroppslige forskjeller framheves og anerkjennes som betydningsfulle, det er disse som er til hinder for like rettigheter, og så arbeider man for å tilrettelegge for at alle skal ha like muligheter i samfunnet derifra gjennom universell utforming og andre tiltak. Den såkalte sosiale modellen innenfor tverrfaglig funksjonshemmingsforskning argumenterer for at funksjonshemming er noe ganske annet enn funksjonsnedsettelser (Oliver, 1990). En funksjonsnedsettelse medfører ingen determinert reduksjon av livskvaliteten. Dersom samfunnet legger til rette for det, kan plager eller hemming ved en funksjonsnedsettelse fjernes eller reduseres, og det samme kan sårbarheten.

Et sted i boka framstiller Grue det som at alt han har oppnådd, har handlet om å unngå å bli forsømt av velferdsstatens hjelpeapparat. Han underliggjør «hjelpeapparatet», og skaper en eventyrstruktur omkring tilgangen til det:

Det finnes et hjelpeapparat. Det er et tungt apparat å drive. ... Hjelpeapparatet ligger i kjelleren, ned en trapp og inne bak en dør, og døren er låst, og nøkkelen er forlagt.

I skyggen av hjelpeapparatet finnes en annen verden, en annen fremtid. Det er denne fremtiden jeg har sett i øyekroken, har flyktet fra. Alt arbeidet jeg har utført, har dreid seg om å unngå dette livet, som ikke anerkjennes som et liv (2018, s. 78).

Hjelpeapparatet er altså livsviktig som hjelper, og livsfarlig som motstander. Liminalfasen Grue presenterte leseren for, å tilhøre to verdener, innebærer å brått kunne dumpe ned i kjelleren, uten å få opp døra til hjelpen, som en levende død. Fra et menneskerettighetsperspektiv er det menneskets verdighet som krenkes, det iboende menneskeverdet som skal sikre oss mot umenneskelig behandling. Statusen som trengende er ikke anerkjent, og en tilstand uten rettigheter som oppfylles, står utenfor definisjonen av selve livet. Grue sier han er opptatt av områder der rettig- 
heter blir feil ord, noe som glipper unna rasjonell beskrivelse (Grue, 2018, s. 41). Kritikken mot menneskerettighetsdiskursen har ofte handlet om en hulhet i kjernen: $\mathrm{i}$ begrepet menneske. Det å få sine rettigheter anerkjent forutsetter at man først har gjort seg gjeldende som menneske. Betydningen av O’Briens tittel å bli et menneske utkrystalliseres, det samme gjør betydningen av å kunne hevde sitt «jeg».

Velferdsstatens menneskesyn er under lupen i Grues bok. Grue anser kulturen og den politiske økonomiens bærende idé som at «mennesker enten er bidragsytere eller utgiftsposter» (Grue, 2018, s. 82-83). Den store fortellingen om syke og funksjonshemmete i vår tid formuleres gjennom økonomiske termer og dreier seg om snyltere, ekte ofre og gode hjelpere. Grue reflekterer over hvordan dette gir seg utslag i selvforståelsen, og ser sin tidligere klokketro på at han kan kompensere for sin egen funksjonsnedsettelse med «talent, viljestyrke og arbeidsevne» som et utslag av kulturen. En leser kan spekulere på om ikke familiekulturen oppsummert i familiemantraet «opp igjen» også bidrar her, og om ikke den uensartete hyllesten til foreldrenes innsats og moral kanskje skjuler en sårbarhet som ikke skal formuleres i bokform. Men uansett, dersom det er slik at det er de spektakulære menneskerettighetsbruddene som best legges merke til, er det også lett å innbille seg at det ikke foregår menneskerettighetsbrudd i velferdsstaten $i$ et demokrati, der bruddene skjer per brev, er byråkratiske, og der subjektet ses som fragmentarisk. Å «mislykkes» i samfunnet blir desto mer en privat erfaring og en individuell feil. Mange kampanjer fremmer en gruppes rettigheter basert på sårbarhet (som Metoo eller Black Lives Matter), men som A. Margareta Dancus, Mats Hyvönen og Maria Karlsson påpeker fra et sårbarhetsperspektiv: Marginaliserte liv medieres ofte på måter som blokkerer medlidenhet (Dancus et al., 2020, s. 4). Kategoriseres et subjekt langt nok ute på offer-flanken, anerkjennes det kanskje som et subjekt som trenger hjelp, men ikke som et som er autonomt: Behovet for å klare seg selv blir desto mer akutt.

Hva ville skje om hjelpeapparatet lyktes, spør Grue, ville alle da be om hjelp? Fantasien om hjelpeapparatet Grue presenterer i boka, er en påminnelse om at et liv uten nødvendig hjelp har likhetstrekk med annen isolasjon, som fengsler eller tidligere tiders inhumane anstalter. Sårbarheten kan minskes om samfunnet legger til rette, ifølge den sosiale modellen. Men den kan også økes uavhengig av hvordan selve funksjonsnedsettelsen påvirker det livet som leves, for eksempel gjennom tungrodde prosesser for å få sin stemme hørt og møter med fordommer. En slik sårbarhet kan kalles «patogen», den utløser i seg selv sykdom. Ved å påpeke slike tilfeller kan det blant annet være mulig å befeste hvordan tiltak som i utgangspunktet skulle forbedre individets situasjonelle sårbarhet, kan virke mot sin hensikt (Mackenzie, 2014, s. 39). 


\section{PRIVILEGERT OG HELSESÅRBAR}

Lest med et interseksjonelt blikk på funksjonshemmingsfortellinger vil en kunne påpeke at som hvit heterofilt gift norsk mann av øvre middelklasse med kloke og kompetente akademikerforeldre, er Grues situasjon bedre enn den kunne vært. Boka forteller om folkehøyskole i Danmark, studieopphold ved Berkeley, St. Petersburg og Amsterdam, bryllupsreise til Hawaii og nye akademiske skriveopphold i California. For Grue banker nettopp enkelte av reisene dette poenget inn, og han artikulerer selv poenget krystallklart: «To motsetningsfylte sannheter kan leve side om side. Jeg er privilegert og sårbar, jeg har kommet dit jeg er ved egen innsats, utelukkende fordi jeg lever i et samfunn som anerkjenner denne innsatsen og supplerer den der det trengs» (Grue, 2018, s. 79-80).

Det problematiske er at disse to motsetningsfylte sannhetene ikke er en akseptert dualitet i møte med velferdsstatens aktører som ser subjektet enten som «en utgiftspost» eller «en bidragsyter». Det innebærer at den «vellykkete» siden ikke kan artikuleres uten at man mister saken sin. Det minner om hvordan man, i tillegg til at noen ekskluderes fra grunnleggende rettigheter, skaper «mottakere» og en idé om «verdige mottakere» av dem som får dem innfridd. Dermed kan menneskerettigheter beskrives som en giftig (voldelig) gave, hevder Pheng Cheah i Inhuman Conditions: On Cosmopolitanism and Human Rights (Cheah, 2006, s. 172): Det er både en korrupt gave, som en slags motytelse, og en gave som setter mottakeren i en posisjon som trengende, skaper en avhengighets- og elendighetsidentitet.

«Hjelpeapparatet stiller hundre små krav til hvordan jeg skal formulere behovene mine, til hvordan elendighetsbeskrivelsen skal se ut. Det krever at jeg forstiller meg, for det vil ikke forstå sannheten - at jeg er lykkelig, jeg har det godt og jeg trenger hjelp» (Grue, 2018, s. 80, kursiv i original). En stigmatisert gruppe er ikke nødvendigvis anerkjent, og samtidig må man paradoksalt nok overdrive sin sårbarhet for å få gjennomslag for krav. Grues egen konklusjon er at han «er sliten. Arbeidet tar aldri slutt, det finnes ikke noe endepunkt» (Grue, 2018, s. 80). Enten er man for syk for å føle seg vellykket, og strever med å framstå som friskere enn man er, eller man er for vellykket til å få hjelp av det offentlige, og må snarere framstå som sykere enn man er. Det hele mennesket, det motsetningsfylte subjektet, blir umulig å fronte.

Gjennom boka viser Grue at for ham innebærer forsøkene på å integrere blikket utenfra en utfordrende bearbeiding av sårbarhet, skam og selvfølelse. Siden Grue er en av dem som lever med det han kaller «uvanlige kropper», blir hans kropp gjenstand for blikk i større grad enn vanlige kropper blir, og den blir i tillegg gjenstand for blikk som tilhører ulike profesjoner, blant annet medisinere, fysio- 
terapeuter, lærere. Etatene som skal hjelpe, viser Grue snarere hvor sårbar han er, noe som skaper selvforakt: «I krysspunktet for disse to blikkene, den kontrollerende institusjonen og den gjennomborende klinikken, befinner vi oss, Mark O’Brien og jeg. Er det rart at vi tidlig lærte å forakte kroppene våre, med sin forakt og sin sårbarhet?» (Grue, 2018, s. 40).

\section{STIGMATISERING, SKAM OG SKAMLØSHET}

Å gå fra et «jeg» til et «vi» med O’Brien er ikke en så liketil bevegelse som det kan virke i sitatet over. I boka viser Grue fram sine egne «forhandlinger» om fellesskap med andre med funksjonsnedsettelse. Det er greit å være den ene uvanlige blant de vanlige kroppene, men er man flere, blir ens egen ulikhet plagsomt påtakelig. Derfor (kan man slutte seg til) er det problematisk å være på sommerleir og å beholde den også funksjonshemmede Cecilie som kjæreste etter returen til de "normale» vennene (Grue, 2018, s. 74), eller i det hele tatt å delta i et fellesskap som har funksjonsnedsettelse som fellesnevner. Akademikeren Grue setter andre steder i boka sin egen selvforståelse i sammenheng med Erving Goffmans begrep om stigma som «spoiled identity». Grue utlegger teorien, og forklarer leseren at en selvforståelse som stigmatisert skaper en bare delvis aksept av en selv. Man avviser den delen som «truer med å spre forråtnelse til andre deler. Da er det fristende å prøve å redde deler av seg selv fra seg selv, å si til seg selv at denne delen av meg ikke har noe å gjøre med denne delen, og at denne delen, som er frisk og sunn, den har ikke noe å gjøre med denne delen, som er syk, skadet, råtten» (Grue, 2018, s. 81). De situasjonene der man skiller seg ut, blir skamfulle. «Det er ikke dette jeg vil», sier han. Litt senere i boka poengterer han skammen dette skaper: «Goffmans begrep om stigma er tett forbundet med skam, og skammen er forbundet med en eksistensiell forskyvning. For at stigmaet skal fungere, er det nødvendig at både den stigmatiserte og samfunnet rundt, de normale, er innforstått med at et menneske ikke er som det burde være. Skammen følger av at noe er grunnleggende galt, at noe ikke er som det skulle ha vært. At livet leves på gale premisser» (Grue, 2018, s. 137).

Skam er knyttet til noe man ikke er, noe som er feil med en, som individ, og blir en sterk, negativ følelse, og et tabu. Skammen har i vår tid blitt en privat, indre følelse, og i seg selv ensom å bære, den er ikke rasjonell. Grues beretning kopler sårbarhet og skam, motstand og skamløshet sammen. Sårbarhet kjennetegnes ved å skape affekt, hevder Anu Koivunen, Katariina Kyrölä og Ingrid Ryberg (2018, s. 7): Skam er en av disse. Frykt, forakt og avsky er andre. Sammen med stigma og 
skam går en følelse av utsatthet - en ubehagelig blottstilling - og vegring mot å påminnes sin ensomhet som en bestandig del av tilværelsen.

Sammenhengene har direkte implikasjoner for rettighetskrav. Om erfaringen er at «stigma smitter», som Grue/Goffman sier, er det komplisert å drive rettighetskamp basert på felles sårbarhet.

Den politiske tenkeren Jill Locke har teoretisert omkring skammens motsats skamløshet i «Klagesangen over skammens død» (2018). Locke ser skamløshet som en protest mot det bestående: Skammen disiplinerer subjektet, gir det visse normer som ikke skal overtres. Gjemmer man seg i skam, forblir reglene uforandret. Klagesangen over skammens endelikt er en ytring for å stanse framskritt og å beholde makt. Den skamløse er en trussel mot samfunnets naturaliserte orden. Hva som kategoriseres som skamløst, handler også om hva som skal forbli innenfor det private domene, og dermed er dette en kamp om hva som egner seg for offentligheten. I veien mot en skamløs utsigelsesposisjon protesterer Grue mot å ta imot en korrumperende gave med takknemlighet, for å på den måten forbli i posisjonen velferdssamfunnet tildeler ham, den som skal hjelpes, eller eventuelt forsømmes, alt ettersom det passer. Man er blitt den som sier «jeg» og stiller krav, man kan gi seg selv agens og hovedrollestatus i sin egen fortelling. At dette er en radikal, uventet og skamløs handling, understrekes av Grues såre refleksjoner om opplæring i selvforakt, men også når han med en karakteristisk ironisk distanse påpeker at han er blant dem som mangler «anstendigheten til å innordne oss de narrative mønstrene» (2018, s. 113, min utheving). Grues handling som jeg-forteller er dermed også å framtre som skamløs, den viser i seg selv en vei ut av skammen.

\section{KULTURELL REPRESENTASJON}

I lesningen av Grues bok ser man at det ikke bare er forfatterens posisjon vis-a-vis velferdsstaten som gjør fortellingen komplisert å målbære (behovet han beskriver som «å være så lite sårbar som mulig, for å fremme ubestridelige krav»). Det handler også om mangel på form, definisjoner og språk. Woolf beskrev, som jeg viste innledningsvis, treffende misforholdet mellom kroppens betydning og den manglende representasjonen i litteraturen på sin egen tid. Hun hevder videre at hva man lærer å sette ord på, gjennom litteraturhistorien, er kjærlighet og abstraksjoner, mens beskrivelser av hodepine og skjelving er fattigslige. «Tusen små øyeblikk går udokumentert», skriver også Grue, og gjør sitt for å skildre "the daily drama» for eksempel ved å kunne kle på (Grue, 2018, s. 29) eller reise seg (Grue, 2018, s. 113-114). Å ha et språk som kan romme ens væren, er eksistensielt: 
Det var en tid jeg ikke visste hva eller hvem jeg var. Jeg manglet kategorier som var mine egne. Mitt inntrykk av meg ble formet av mange små møter og av like mange forventninger. Jeg visste ikke hva slags kropp jeg var.

Jeg visste ikke hva slags kropp jeg var, for jeg manglet en fortelling (Grue, 2018, s. 148).

Narrative mønstre og språk er nødvendige for en tydelig selvforståelse. Samtidig framstår Grue som en forsvarer for (eller interessert i) det som nettopp ikke fullt ut lar seg kategorisere. Selv om Woolf ikke går inn på dem, eksisterer det jo visse etablerte skjema for en fortelling om funksjonshemming, sårbarhet og menneskerettigheter. Sammenhengen skrives tydelig ut i Grues selvframstilling når han fortsetter, blant annet med henvisning til H.C. Andersen:

Det finnes mange fortellinger om barn som er svake eller sykelige. Nesten alltid skjer én av to ting: De friskner til eller de dør. De er stygge andunger eller standhaftige tinnsoldater (2018, s. 148).

Disse narrative mønstrene er kritisert fra både tverrfaglig funksjonshemmingsforskning og litteratur og menneskerettigheter. David Mitchell og Sharon Snyder kaller det «narrative prothesis» når funksjonsnedsettelser i fiksjonen brukes som en slags krykke for persontegningen eller plottet (2000), snarveier til spenning, medlidenhet eller fordømmelse. Charles Dickens Tiny Tim-karakter, den lille svake gutten i A Christmas Carol, og Heidis venninne i rullestol i Alpene, som bare er snill, i Johanna Spyris barnebok Heidi, er to karakterer som typisk viser fram en affektskapende sårbarhet knyttet til nedsatt funksjonsevne.

Litteratur og menneskerettighetsfeltet har også lest ut noen seiglivete mønstre. Det dreier seg om at det er de aller mest krenkende historiene, fortellingene som får leserne til å gispe og si «dette må endres». Fordi menneskerettighetsdiskursen skaper affekt (Mullins, 2019, s. 207), bør litterær stil og retorikk granskes nøye. I studien Human Rights Inc. viser Joseph Slaughter at dannelsesromanen og menneskerettighetsjusen oppstod omtrent samtidig og underbygger hverandre: Dannelsesromanene har den frie og fullstendige personlighetsutviklingen som mål, de er «enabling fictions» $(2007$, s. 44). Målet om det autonome mennesket står fast, alle andre blir bikarakterer eller karakterer det går dårlig med, mens hovedpersonene enten lykkes til tross for alle hindre, eller går under.

«Elendighetsbeskrivelsen» Grue har inntrykk av at det offentlige krever av ham, der han reduseres til en av de elendige, den stakkarslige, og det offentlige til en velgjører, en helt, er velkjent i litteraturhistorien. Men for Grue handler fortellingen hans verken om å friskne til eller dø, det er heller ikke noen dramatisk overlevelse; 
som tittelen understreker, leves et liv som både er likt og ulike andres. «Hva da med oss som blir voksne, men fortsetter å være svake?» spør Grue: «Hva skjer med oss som fortsetter å leve våre underlige liv, som forblir i annerledesheten, vi som ikke har anstendigheten til å innordne oss de narrative mønstrene?» (2018, s. 148).

Så hvordan skal helsesårbarhet skildres? I en scene i boka jeg opplever som viktig, beskriver Grue en filmvisning der han er invitert som paneldeltaker i etterkant. Filmen er The Sessions, en fiksjonsfilm om Mark O’Briens liv. O’Brien, som lå i jernlunge, er berømt for å ha skrevet åpent om sitt seksualliv, der han hadde «sessions» med en seksualterapeut, som altså filmen handler om. I filmen gestalter en høy og frisk skuespiller O’Brien. Grue «kvier seg for å se for nøye på sårbarheten», og alt det filmen «blottstiller», som er knyttet til hans egen uro for ensomheten. Samtalen etter filmvisningen tar tak i tematikken uten å forholde seg til erfaringene, i et rom fullt av mennesker som deler noen av disse: Kroppene forsvinner, slik Grue skildrer det, idet temaet i filmens tematikk allmenngjøres, idet erfaringene skal bli til politikk. Det er flere sider ved måten Grue reflekterer om filmvisningen på, som har direkte betydning for de narrative mønstrene han selv gjør opprør mot, eller forsøke å finne opp, og skamløshet:

Filmen var oscarnominert, slik filmer av dens slag gjerne blir, som en anerkjennelse av det noere og sårbare og allmennmenneskelige som ikke er allment i det hele tatt, for O’Briens erfaringer var så spesielle at de var fjerne også for meg, jeg kan ikke og burde ikke få lov til å identifisere meg med ham, påberope meg hans offerrolle. Sårbarheten hans var ekstrem, og når ekstreme livserfaringer blir en fortelling, medfører det en risiko for at den som forteller, også om det er den samme som har erfart, øver vold mot selve erfaringen (2018, s. 43, kursiv i originalen).

For det første ironiserer Grue over sårbarhet i kursiv, som en kommersiell vare i et spesifikt kulturmarked. Den kursiverte sårbarheten er sårbarhet som har antatt varekarakter, den er like mye en protese som funksjonshemmingene er for Snyder og Mitchell. Utsagnet (temaet) er viktigere enn hva som blir sagt (det er viktig i seg selv at noe sies). Sårbarhet mobiliserer affekt, medlidenhet og spenning, og om man bruker salgstall og affekt som parameter, er det ikke så nøye hva som sies, eller hvem som sier det. Dermed fronter gjerne hvite, vestlige menneskerettighetsforkjempere en sak i menneskerettighetsfortellinger, eller en frisk skuespiller en syk i en film om hva det betyr å ha rett til seksualitet.

For det andre beskriver Grue her en «ekstrem» sårbarhet, på grensen av det som lar seg representere, fordi det er unikt. Skal det allmenngjøres, må det gi gjenklang hos andre, som nettopp ikke har erfaringene. Dermed forsvinner det eksakte i en 
tillemping. Det som kan formidles, blir en redigert versjon; denne kan til gjengjeld altså hylles for sitt universelle innhold. Men den ekstreme sårbarheten er en ensom erfaring. Den kan verken selges eller kjøpes, og er ikke fullt ut mulig å identifisere seg med. Den ekstreme sårbarheten tegner opp en normativ etisk grense for identifikasjon; man/han burde ikke få lov. Menneskerettighetsorganisasjonene og aktivistene bruker tematikken, men hvor blir det av erfaringene?

\section{SÅRBARHETENS «PUSH AND PULL»-BEVEGELSER}

Grues protest mot å identifisere seg med O’Briens rolle peker på et akutt etisk dilemma $\mathrm{i}$ formidlingen av menneskerettighetsbrudd, sykdomssårbarhet og sjeldne kroppslige erfaringer. Spørsmålet er videre ikke bare som hos Gayatri C. Spivak, «Hvem kan snakke for den underordnete?», men: Hvordan kan samtalen dem imellom foregå? Skammen i salen ligger over det som kan sies, alle «kvier seg» for å se seg selv i O'Brien. O’Brien er nettopp også en identifiserbar figur, med et potensial for gjenkjennelse, men det han minner om, er umulig å artikulere for en selv og andre. Han er en inspirasjon for Grue, også en som får ham til å måtte konfrontere sin ytterste sårbarhet, men «jeg kviet meg for å se nøye på alt det O'Brien blottstilte, ubehaget han la fram, for det kjente jeg igjen i meg selv» (2018, s. 42).

Psykiater Finn Skårderud har påpekt at den ultimate skammen er «smerten ved å se seg selv som en som ikke fortjener å bli elsket» (2001, s. 38). I tillegg er funksjonshemmetes seksualitet både et område for nysgjerrighet, sett på som lite attraktivt, og funksjonshemmete skildres gjerne som aseksuelle i film og litteratur (Kim, 2011). Det er en rekke tabuer som gjør at funksjonshemmete hva seksualitet angår, må kjempe for å ses på som hele mennesker, og et område det offentlige ikke vil blandes inn i på ulikt grunnlag. Grues skildring viser at de sosiale tabuene hindrer formidling og samtaler. Å løfte det private som filmen handler om, ut i offentligheten annet enn som abstraksjon, skaper frykt både for å overskride private grenser og offentlighetens normer. Man kan kanskje aldri finne et språk som fullt ut dekker en helt unik erfaring. Men scenen viser at for at en sårbarhetens politikk skal finne sted, må skamløshetens etikk berede grunnen.

Slik kaster scenen lys over sårbarhet som en rekke "push-and-pull movements» (Dancus et al., 2020, s. 7). Dancus, Hyvönen og Karlsson sier at «vulnerability moves us, not only towards each other, but also against one another» (Dancus et al., 2020, s. 7). Grues bok bidrar til at vi i tillegg ser hvordan konfrontasjon med sårbarheten utløser en rekke "push-and-pull»-bevegelser innenfor en selvbevissthet, som særlig angår identifikasjon med den ekstreme sårbarheten og, i forlengelsen av dette, frykten for et kjærlighetsløst liv. Dobbeltgjengeren O’Brien får særlig 
funksjonen som en igangsetter for disse bevegelsene i framstillingen. Skammen er den andre viktige igangsetteren for Grues bokprosjekt, forstått som en utfordring for forfatteren i å selv våge å eksponere sin sårbarhet og se seg selv som et helt menneske. Dette gjør at Grue stadig vender tilbake til O’Brien, for å finne fram til en forsoning med sin egen kropp og sin egen situasjon - også i en lettelse over å være på et bedre sted.

\section{LENGSEL ETTER FORM}

Grues innsikt er altså at «når ekstreme livserfaringer blir en fortelling, medfører det en risiko for at den som forteller, også om det er den samme som har erfart, øver vold mot selve erfaringen». Dette angår også forfatterens eget prosjekt og hvordan vi leser Jeg lever et liv som ligner deres.

Det tok ti år å finne de rette ordene og den rette formen. Men i Jeg lever et liv som ligner deres har den ikke-fullt-ut-representerbare sårbarheten i kulturen sitt motstykke i de ignorerte styrkene. Et eksempel er Grues utlegning om rullestolens fortreffeligheter og kulturhistorie, der Grue har en oversikt andre mangler. Å være lenket til rullestolen er en meningsløs klisjé som viser et utenfrablikk på mobilitet og stasis. For en rullestolbruker er den nettopp veien til frihet, en hest, et skip, noe å ri inn i solnedgangen på (for å bli i klisjeene).

Den spekulative skjønnlitteraturen er et annet sted for alternativene: Grue peker på superhelthistorier, science fiction-romaner, fortellinger der umulige handlingsforløp, karakteregenskaper og settinger opptrer som selvfølgelige. Men framfor alt demonstrerer Grues essayistiske stil i Jeg lever et liv som ligner deres lek med narrative mønstre som selv unndrar seg enkel kategorisering. I margen kan det stå «Ankeerklæring til Trygderetten. 2. 9. 86» (2018, s. 70) eller «Michel Foucault» (s. 52), og sitater fra saksgang, offentlighet og klinikk, filosofi og litteratur inngår i teksten. Prosaen er like variert. Stilen er gjerne saklig, men også leken. Et eklatant eksempel er personifiseringen av hjelpeapparatet, som stiller spørsmål, nekter å forstå svarene, smiler skjelmsk. I en passasje skrives Hjelpeapparatet inn som Bøygen fra Peer Gynt:

Meg: Gi svar!

Stemmen: Meg selv.

Meg: Det gjør ikke saken noe klarere. Hva er du?

Stemmen: Det store Hjelpeapparatet.

Meg: Så hjelp!

Hjelpeapparatet: Gå utenom, Grue! 
Meg: Igjennom! (Slår og hugger.)

Hjelpeapparatet: Hjelpeapparatet, Grue, det eneste.

Det er Hjelpeapparatet som er sårløst, og Hjelpeapparatet som fikk mén. Hjelpeapparatet som er dødt, og Hjelpeapparatet som lever.

... og så videre. Atter og fram er like langt, ut og inn er like trangt.

[...].

I min familie går vi ikke utenom. (Grue, 2018, s. 136).

Skildringen gir også rom for en nyfortolkning av Hjelpeapparatets mas om opplysninger som en fuge av Bach. Slik karakterisert skapes velferdsstatens papirmølle om til en barokk struktur, noe vakkert, men også noe som beveger seg i sirkel gjennom små variasjoner over det samme temaet. Ved å gripe tilbake til Ibsens etablerte mønstre gir Grues aktuelle fortelling om rettighetskamp og sårbarhet i velferdssamfunnet røtter i norsk kultur. Underliggjøringene er humoristiske og dypt alvorlige, «depresjonens språk» er med i teksten, men nå som et marginalt og ikke avgjørende aspekt.

Dersom fortellingene som utforsker sårbarheten på en nyansert måte, mangler, og man kun har klisjéfylte fortellinger om motgang og styrke, blir det kulturelle rommet for forståelsen av funksjonshemming svært trangt. Ikke minst skjuler det måten funksjonshemming kan utspille seg på i velferdssamfunnet. Det er stort rom for å skape nye fortellinger, og Grue gjør det. Dette er også en årsak til at Grues sakprosafortelling er viktig. Anerkjennelse beror på erfaringer med og gjenkjennelse av lidelse. For at det skal skje, må noen fortelle noe, og noe må fortelles på nye måter. Risikoen for tabuisering av uvanlige kropper aksentuerer betydningen av vitnesbyrd, selvframstillinger og at alle har tilgang til ordet og skriften. Den personlige historien kan opplyse de ukjente ansiktene, og hjelpe oss å se egne privilegier, skape solidaritet på tvers av forskjeller (Slaughter, 2007). Selv om ingen fortelling er en direkte avbildning av virkeligheten, er det heller ingen skuespillere som skal mime akkurat Grues uvanlige kropp. I boka får denne kroppen plass med detaljene beskrevet: vinkelen på armene, skoene med innleggssåler, osv.

Ifølge Schaffer og Smith handler livshistorier om menneskerettighetsbrudd om motstandsdyktighet og kamp: «The primary gain comes with the legitimating of individual loss and suffering, and the embedding of the individual story in a larger story of human rights violations for the purposes of building a case and motivating action» (2004, s. 37). Koivunen, Kyrölä og Ryberg hevder at et enkelt narrativ fra sårbarhet til motstand driver mye av feministiske sårbarhetsanalyser (2018). Selv om veien ut av skammen også i lesningen av Grue kan framstilles som en utvikling, 
handler det ikke her om å følge de etablerte narrative mønstrene der motgang gjør sterk, historier som viser hvor usårlig man er. Tvert imot er veien ut av skammen å akseptere overfor seg selv hvor sårbar man faktisk er, og vil fortsette å være. Grues mål formuleres snarere som å akseptere stauts quo: «I papirene som står på kontoret mitt, forblir jeg et barn med en diagnose, et sårbart barn. Jeg forblir et barn som vil trenge hjelp og oppfølging hele livet. Og dette er sant» (2018, s. 79). Gjennom boka stiller og besvarer forfatteren spørsmål om hva motstand er, eller innebærer. Dette skjer uten en tilsvarende betoning av kampiver for tilværelsen og høylytte rop som skal skape endring og handling. Snarere betones livsfortellingen, som strategi:

Hva består motstand i? Et annet språk, en annen holdning. Å fortelle åpent, uten skam. Mitt liv er forskjellig fra mange andres. Det er like fullt mitt liv (Grue, s. 138, min utheving).

Motstanden handler om å få uttrykke seg som et menneske som er annerledes uten skam. Dette klinger nærmere til Judith Butlers ideer om det prekære i Precarious Life. For henne blir man menneske («how the human comes into being») ved å få sin utsatthet og sårbarhet anerkjent (Butler, 2004, s. 49). I Grues beretning om motstand handler anerkjennelse om selvforståelse:

Det er ikke slik at det som ikke dreper deg, gjør deg sterkere, tvert imot, det som ikke tar livet av deg, kan gjøre deg mer ydmyk, mer villig til å anerkjenne sårbarheten. Jeg håper det er det som skjedde (2018, s. 128).

Målet for utviklingen er ikke definert, det tilhører snarere det som ligger utenfor, det forfatteren strever med å sirkle inn: «Jeg vil ha noe jeg ikke kan få. Jeg vil ha en annen verden. Jeg vet ikke hvordan den ser ut. Jeg vil at den skal være åpnere, friere. Jeg vil at det skal være plass til meg og alle jeg er glad i» (Grue, 2018, s. 132). Setningene er tilsiktet åpne i en bok som preges av språklig presisjon, fremmedord, vitenskapelige og kulturelle referanser. Ambisjonen er delvis å gi blaffen i andres mål og akseptere en ikke-utvikling. I noen tilfeller dreier det seg om å få verden tilpasset ham, ikke omvendt, som ved bestille en skreddersydd frakk der kroppen virkelig kommer til sin rett. I andre tilfeller dreier det seg om å avvise andres krav, ved å ikke gjengjelde utenfrablikket, ikke forlenge en utmattende dialog, og akseptere kroppens begrensninger for å utvikles og forbedres. Eksempler i så måte er å slutte med fysioterapi som ikke virker, og å ikke oppsøke leger med mindre det er noe spesifikt han vil ha hjelp til. Det vanskeligste er å slutte å kjempe for å oppnå noe som koster for mye: Å leve som andre innebærer i Grues familie studieopp- 
hold ved prestisjefylte utenlandske universitet. Å innrømme at en reise ikke ble som den burde, og avbryte et påbegynt prosjekt, kan likevel også være det riktige.

Slik kvitter Grue seg med den «patogene sårbarheten»: «Jeg har ikke god nok tid til å bruke den på ritualer fra noen andres religion, til å fylle en rolle bestemt av andre. Jeg fortsetter likevel inn i det ukjente, men i det minste i en retning jeg selv har bestemt» (2018, s. 130). Selv om Grue ikke nevner foreldrene her, kan en leser som før nevnt tenke at familieetikken har en slagside og at Grue implisitt beskriver en løsrivelse også fra denne.

Grue kan i motsetning til O’Brien, «som har tatt til seg klinikkens språk» (Grue, 2018, s. 42), avgrense seg selv og skjerme seg fra dette språket og blikket. Av avgjørende betydning synes blikkene som ser på ham med kjærlighet å være. Det er sønnens blikk, som ser pappas hjelpemidler som leker, og gir Grue tilbake en virkelighetens underliggjøring gjennom barneblikket (2018, s. 29). Det er foreldrenes blikk, og vissheten om at de aldri ville gi opp arbeidet for sønnens rettigheter. Det er ikke minst ektefellen Idas blikk, som står for et sinne Grue har mistet, og naturligvis for den elskedes blikk. Å se verden gjennom Ida skaper en defamiliserende vending. Der Grue er skamfullt oppmerksom på at stigma smitter, blir Ida snarere sint når ektemannens menneskeverd reduseres, og rettigheter ikke kan tas for gitt (2018, s. 151, 149).

Boka er, lest fra denne vinkelen, ganske romantisk i all sin teoretisering om rettigheter og sårbarhet. Det O’Brien aldri fikk i sitt korte liv, var nærhet, familie, barn. Grues liv ligner hans, men på viktige områder overhodet ikke. Grue skriver at han ikke vet hvilken annen verden det er han ønsker seg. Men etter endt lesning ser man at memoarene stiller abstraksjonen kjærligheten og ideologien kjernefamilien opp som et viktig svar. Med tanke på at Grue forstår sitt liv som mulig på grunn av «foreldre som mestret hjelpeapparatet», er kjernefamilien han etablerer, også noe av en sikkerhet, en forsikring, der velferdsstaten ikke trår til. Slik er denne verdien også en påminnelse om at den private omsorgen, ektefellen og på sikt egne barn også i våre dager står som garantist, eller for et håp om garanti, for at basale omsorgsoppgaver utføres. Men også for en rehabilitering av en sårbar selvfølelse er en verden som ser på en med kjærlighet og omsorg, nødvendig. Implikasjonene for sårbarhet, skamløshet og menneskerettigheter er ikke nødvendigvis romantiske, men boka peker på betydningen av det ikke-dømmende/ikke-forenklende blikket. Boka holder opp et omsorgsetisk alternativ: en etikk begrunnet i enkelttilfellet, ikke i abstraksjonene, der menneskelig sårbarhet anerkjennes som gjensidig forpliktende.

For leseren kan det se ut som selvmarkeringens «jeg», og en avklaring av identifikasjonen med «ham» (O’Brien), er en forutsetning for å finne «henne» (Ida). Det 
er både det som gir muligheten til «å leve et liv som er radikalt annerledes enn hans» (Grue, 2018, s. 46), og som kan skape en plattform for et fellesskap med mennesker med funksjonsnedsettelser som stiller ubestridelige krav.

Grues bok er i dette lyset en slående beretning om at anerkjennelse både er relasjonelt konstituert og utvikles gjennom en forpliktende relasjon med seg selv. Det blir komplisert å skrive om seg selv og eksponere sårbarheten om man er redd for å miste sin tilgang til det universelle, det umerkete, som beror på en identitet som identisk alle andre, noe annet enn å ligne. Å bære vitne om skammen offentlig som et selvbiografisk «jeg» er imidlertid en åpning av et fortiet tema. Grues hele menneske inkluderer svakhet og styrke, mens apparatet rundt ham tar avgjørelser om hvorvidt han og andre er tilstrekkelig i behov for å få hjelp. Grue viser tydelig hvordan velferdsstatens utvikling til en «konkurrencestat»(Pedersen, 2011) legger stein til byrden.

Grue løfter dokumentasjonen av sitt liv ut av de båsene han selv har satt dem i (diskursene), og ut av arkivene (permene) og ut i den bredere offentligheten. Boka som foreligger, gir langt mer enn en personlig utvei. Den er et avansert patografisk vitnesbyrd om helsesårbarhet, rettigheter og skam i velferdsstaten. En vei ut av skammen er en aksept av sårbarhet, men ingen forherligelse av den. Boka insisterer på at selv om man ikke kjenner igjen sin egen fortelling i kategoriene og de narrative mønstrene som er etablert, finnes den; selv om man ikke får sine rettigheter anerkjent, finnes menneskeverdet, og å ha en uvanlig kropp er ingen skam, selv om det kan være mer slitsomt. Det er lov å bli sliten, lov å streve med å finne en farbar vei - faktisk også lov å ikke bare si «opp igjen» om og om igjen.

«Jeg tror jeg skriver om meg selv for å forstå verden», skriver Grue i passasjen jeg siterte innledningsvis (Grue, 2018, s. 41). Også leseren forstår mer av verden gjennom Grues vitnesbyrd om sitt liv og den kroppen han er, etter at han har funnet sin egen litterære form og skreddersydd kategoriene. Grues bok utvider repertoaret av fortellingene som vanligvis inngår i litteratur og film, og problematiserer kulturens utelatelser og forestillinger, politikken som til enhver tid omgir kroppene våre, og hva som er vanlig og uvanlig. Etter endt lesing av Grues bok er det ikke minst lett å slutte seg til Woolfs betraktning: «It becomes strange indeed that illness has not taken its place with love and battle and jealousy among the prime themes of literature.» 


\section{REFERANSER}

Anker, E. S. (2012). Fictions of Dignity: Embodying Human Rights in World Literature. Cornell University Press.

Bergenmar, J. (2020). Vulnerability and Disability in Contemporary Nordic Literature: Linn Ullmann's Grace and Sofi Oksanen's Baby Jane. I A. M. Dancus, M. Hyvönen \& M. Karlsson (Red.), Vulnerability in Scandinavian Art and Culture (s. 151-172.). Palgrave Macmillan.

Butler, J. (2004). Precarious Life: The Powers of Mourning and Violence. Verso.

Butler, J. (2016). Rethinking Resistance and Vulnerability. I Butler, J., Gambetti, Z. \& Sabsay, L. (Red.). Vulnerability in Resistance, Duke University Press. https://doi.org/10.1515/9780822373490-004

Cheah, P. (2006). Inhuman Conditions: On Cosmopolitanism and Human Rights. Harvard University Press.

Dancus, A. M., Hyvönen, M. \& Karlsson, M. (2020). Mobilizing Vulnerability in Scandinavian Art and Culture. I A. M. Dancus, M. Hyvonen \& M. Karlsson (Red.), Vulnerability in Scandinavian Art and Culture, (s. 1-15), Palgrave Macmillan. https://doi.org/10.1007/978-3-03037382-5

Duger, A., Adams, H., Hillman, A., Leibowitz, T. \& Klein, J. (2020, 5. utgave). Disability, Health, Community Living and Human Rights. Health and Human Rights Resource Guide.

https://www.hhrguide.org/2014/03/21/disability-and-human-rights/

Ganteau, J. (2015). The Ethics and Aesthetics of Vulnerability in British Fiction. Routledge.

Goldberg, E. S. \& Moore, A. S. (2012). Introduction. I E. S. Goldberg \& A. S. Moore (Red.), Theoretical Perspectives on Human Rights and Literature (s. 3-16). Routledge.

Grue, J. (2018). Jeg lever et liv som ligner deres: En levnetsbeskrivelse. Gyldendal.

Hunt, L. (2007). Inventing Human Rights: A History. W.W. Norton.

Kim, E. (2011). Asexuality in Disability Narratives. Sexualities, 4(4), 479-493. https://doi.org/ $10.1177 / 1363460711406463$

Koivunen, A., Kyrölä, K., Ryberg, I. (2018). Vulnerability as a Political Language. I A. Koivunen, K. Kyrölä \& I. Ryberg (Red.), The Power of Vulnerability: Mobilising Affect in Feminist, Queer and Anti-racist Media Cultures (s. 1-26). Manchester University Press, 2018.

Locke, J. (2018). Klagesangen over skammens død. Kultur og Klasse, 46(125), 13-48. https://doi.org/10.7146/kok.v46i125.105537

Mackenzie, C. (2014). The Importance of Relational Autonomy and Capabilities for an Ethics of Vulnerability. I C. Mackenzie, W. Rogers \& S. Dodds (Red.). Vulnerability: New Essays in Ethics and Feminist Philosophy (s. 33-59). Oxford University Press.

Mitchell, D. \& Snyder, S. (2000). Narrative Prosthesis: Disability and the Dependencies of Discourse. University of Michigan Press.

Mullins, G. (2019). Routing Emotions, Forming Humans. Affect, Aesthetics, Rhetoric. I C. Parikh (Red.), The Cambridge Companion to Human Rights and Literature (s. 206-216). Cambridge University Press. https://doi.org/10.1017/9781108698511.016

O’Brien, M. (2012). How I Became a Human Being: A Disabled Man's Quest for Independence. University of Wisconsin Press.

Oliver, M. (1990). The Politics of Disablement. Macmillan Education.

Pedersen, O. K. (2011). Konkurrencestaten. Hans Reitzels Forlag.

Schaffer, K. \& Smith, S. (2004). Venues of Storytelling: The Circulation of Testimony in Human Rights Campaigns. I Life Writing, (1)2, 3-26. https://doi.org/10.1080/10408340308518258

Simonhjell, N. (2010). Krøplingkroppar: Om littercer framstilling av merkte, aldrande og funksjonshemma kroppar i Lars Ramslies Biopsi og Stig Saterbakkens Siamesisk. Avhandling for graden ph.d. Universitetet i Agder, Fakultet for humaniora og pedagogikk, Institutt for nordisk og mediefag. 
Skårderud, F. (2001a). Tapte ansikter. I T. Wyller (Red.), Skam: Perspektiver på skam, are og skamløshet i det moderne (s. 37-52). Fagbokforlaget.

Slaughter, J. R., (2007). Human Rights Inc.: The World Novel, Narrative Form, and International Law. Fordham University Press. https://hdl.handle.net/2027/heb.31763

Xiang, S. (2019). Narrating the Human Person. I C. Parikh (Red.), The Cambridge Companion to Human Rights and Literature (s. 129-140). Cambridge University Press. https://doi.org/ 10.1017/9781108698511.016

United Nations General Assembly. (2006). Convention on the Rights of Persons with Disabilities. A/RES/61/106, Art. 1. https://www.un.org/development/desa/disabilities/convention-onthe-rights-of-persons-with-disabilities.html

World Health Organization. (2011). World Report on Disabilities. https://disabilityinclusion.msf.org/assets/files/WorldReport_eng.pdf

Vold, T. (2014). Ansatsens signatur. I T. Steen, H. J. Orning, T. Vold \& R. Jacobsen (Red.), Den besvoerlige historien. Tre tekster - ni fors $ø$. Forlaget Oktober.

Woolf, V. (1926). On Being Ill. https://thenewcriterion1926.files.wordpress.com/2014/12/woolfon-being-ill.pdf 